\title{
Peran Mediator dalam Penyelesaian Sengketa Ekonomi Syariah di Pengadilan Agama Sleman
}

\author{
Dwi Wiwik Subiarti \\ wiwikd30@yahoo.com
}

\begin{abstract}
This study aims to examine and analyze the role of mediators in resolving sharia economic disputes in Sleman Religious Court. We also aim to determine the obstacles faced by mediators when mediating sharia economic disputes in Sleman Religious Court. This research is a normative legal research using a legislative approach and a case-study approach. Based on the results of the study, we find that the role of mediators in solving sharia economic disputes in Sleman Religious Court is generally unsatisfactory due to several obstacles they face although for some cases of sharia economic disputes the role of mediators has been strong enough to achieve agreement deeds. Though remaining insignificant, the role of mediators has been able to reduce the number of sharia economic cases to be resolved by investigating judges.
\end{abstract}

Keywords: The role of mediators; sharia economic disputes; religious court

\begin{abstract}
Abstrak
Penelitian ini bertujuan mengkaji dan menganalisa peran mediator dalam penyelesaian sengketa ekonomi syariah di Pengadilan Agama Sleman. Bagaimana peran mediator dalam penyelesaian sengketa ekonomi syariah di Pengadilan Agama Sleman. Penelitian ini juga bertujuan untuk mengetahui hambatan yang dihadapi oleh mediator dalam pelaksanaan mediasi sengketa ekonomi syariah di Pengadilan Agama Sleman. Penelitian ini merupakan penelitian hukum normatif dengan menggunakan pendekatan perundang-undangan dan pendekatan kasus. Berdasarkan hasil penelitian dapat disimpulkan bahwa peran mediator dalam penyelesaian sengketa ekonomi syariah di Pengadilan Agama Sleman secara keseluruhan belum mencapai hasil yang memuaskan dikarenakan adanya beberapa hambatan yang dihadapi oleh mediator, meskipun untuk beberapa kasus sengketa ekonomi syariah telah terlihat peran kuat mediator dengan hasil tercapainya akta kesepakatan. Peran mediator telah dapat mengurangi jumlah perkara ekonomi syariah yang harus diselesaikan oleh hakim pemeriksa perkara, namun belum signifikan.
\end{abstract}

Kata-kata Kunci : Peran mediator; sengketa ekonomi syariah; pengadilan agama 


\section{Pendahuluan}

Islam mengakui bahwa manusia memang tidak terlepas dari sengketa dalam kehidupannya. Dalam Al Quran surat Al Baqarah ayat 30 digambarkan bagaimana malaikat mempertanyakan kenapa Allah menjadikan manusia sebagai khalifah di bumi karena malaikat khawatir manusia cenderung melakukan kerusakan dan pertumpahan darah dimuka bumi. Ayat tersebut menggambarkan bahwa manusia mempunyai kecenderungan berkonflik/bersengketa.

Namun, Allah SWT tidak berlepas dari kecenderungan yang merugikan manusia sendiri itu. Untuk mengatasi sengketa yang terjadi antara manusia, Allah SWT telah menganugerahi wahyu yaitu al Quran sebagai petunjuk yang memuat prinsip-prinsip dasar penyelesaian sengketa yang kemudian diwujudkan oleh Nabi Muhammad SAW dalam berbagai bentuk seperti fasilitasi, negosiasi, adjudikasi, rekonsiliasi, mediasi, arbitrase, dan lembaga peradilan ${ }^{1}$. Hampir sama dengan yang dijelaskan dalam hukum perikatan Islam bahwa penyelesaian sengketa pada prinsipnya bisa dilaksanakan melalui tiga jalan yaitu dengan jalan perdamaian (shulhu), arbitrase (tahkim) dan proses peradilan (al Qadla)². Pengertian al Qadla dalam perspektif Islam dapat disepadankan dengan pengertian peradilan menurut ilmu hukum³.

Sulh sebagai upaya penyelesaian sengketa secara damai telah diterangkan dalam Al Quran dan Hadis Rasulullah SAW. Al Quran dalam surat an Nisa ayat 114 mengatakan,"Tidak ada kebaikan pada kebanyakan bisikan-bisikan mereka, kecuali bisikan-bisikan dari orang yang menyuruh (manusia) memberi sedekah, atau berbuat makruf, atau mengadakan perdamaian diantara manusia. Dan barangsiapa yang berbuat demikian karena mencari keridhaan Allah, maka kelak Kami memberi kepadanya pahala yang besar". 4 Rasulullah SAW juga menganjurkan untuk melaksanakan perdamaian dalam salah satu hadis yang berbunyi,"Perdamaian antara sesama orang muslim itu

${ }^{1}$ Syahrizal Abbas, Mediasi dalam Perspektif Hukum Syariah, Hukum Adat, dan Hukum Nasional, Kencana, Jakarta, 2009, hlm. 122.

${ }^{2}$ Gemala Dewi et. al., Hukum Perikatan Islam di Indonesia, Kencana, Jakarta, 2007, hlm. 87.

3 A Rahmat Rosyadi dan Ngatino, Arbitrase dalam Perspektif Islam dan Hukum Positif, Cetakan I, Citra Aditya Bakti, Bandung, 2002, hlm. 30.

${ }^{4}$ Terjemahan Quran Kemenag diambil dari http://quran.kemenag.go.id/., akses tanggal 27 Agustus 2017. 
dibolehkan, kecuali perdamaian yang mengharamkan yang halal atau menghalalkan yang haram". ${ }^{5}$ Sulh adalah akad yang mengakhiri persengketaan antara dua pihak. ${ }^{6}$

Prinsip-prinsip mediasi yang pernah dilakukan dijaman Rasulullah SAW antara lain ketika terjadi perjanjian Hudaibiyah, dimana perjanjian antara umat muslimin di bawah pimpinan Rasulullah SAW dan kaum Quraish tersebut adalah merupakan hasil negosiasi yang panjang yang akhirnya menghasilkan kesepakatan-kesepakatan. Pola mediasi di jaman Rasulullah juga dilakukan pada kasus sengketa rumah tangga. Proses penyelesaian sengketa rumah tangga melalui pihak ketiga yang disebut dengan hakam seperti yang terdapat dalam ayat al Quran surat an Nisa' ayat 35. Ayat ini menganjurkan adanya pihak ketiga (hakam) yang sekarang dikenal dengan nama mediator untuk dapat membantu suami istri mencari jalan penyelesaian sengketa keluarga mereka.

Jika praktek mediasi telah dijalankan pada masa Rasulullah SAW, maka praktek penyelesaian sengketa secara damai juga telah dipraktekkan dalam kehidupan masyarakat Indonesia berabad-abad yang lalu. Musyawarah mufakat merupakan falsafah masyarakat Indonesia dalam setiap pengambilan keputusan, termasuk untuk upaya penyelesaian sengketa. Nilai musyawarah mufakat tersebut diwujudkan dalam sejumlah alternatif penyelesaian sengketa seperti mediasi, arbitrase, negosiasi, fasilitasi dan lainnya.

Sebagai perbandingan, di Amerika Serikat, mediasi dilakukan untuk menyelesaikan sengketa sewa menyewa gedung, gugatan konsumen, perceraian dan pembagian harta, perlindungan lingkungan, petani, debitur dan bank sebagai kreditur untuk mencegah eksekusi ${ }^{7}$. Program mediasi ini dikembangkan oleh Pengadilan Negara Bagian dan Federal, dimana hakim, magistrate, pejabat pengadilan lainnya, atau orang lainnya bukan pejabat pengadilan sebagai mediator yang ditunjuk oleh Pengadilan8. Di Jepang terdapar wakai dan Chotei. Wakai artinya konsep damai, di mana wasit penyelesaian sengketa hanya perlu satu hakim

\footnotetext{
${ }^{5}$ Kitab Sunan Abi Dawnd, jilid 2, Hadist No. 3594, hlm. 304.

${ }^{6}$ Sayid Sabik, Fiqh Sunnah, Juz 3, Dar al-Fath, Kairo, 2000, hlm. 210.

${ }^{7}$ Erman Rajagukguk, Arbitrase dalam Putusan Pengadilan, Cetakan I, Chandra Pratama, Jakarta, 2000), hlm. 110. 
mediator yang bebas untuk mengembangkan tehnik penyelesaian sengketa. Chotei artinya mediasi, di mana penyelesaian sengketanya harus diajukan melalui komisi Chotei ${ }^{9}$. Praktik Wakai telah terbukti berhasil mengurangi penumpukan perkara perdata di pengadilan Jepang sekitar $45-55 \%{ }^{10}$. Keberhasilan wakai ini telah memberi dampak positif pada lebih efektif dan efisiennya proses peradilan perdata dalam hal waktu dan biaya yang dikeluarkan oleh para pihak. Peran aktif hakim (mediator) dan kemampuannya membuat proposal wakai dipercaya menjadi salah satu faktor penting dalam menunjang keberhasilan wakai. Fenomena pengadilan menyelesaikan sengketa dengan cara mediasi, disamping cara litigasi, merupakan pengembangan dunia hukum modern abad ke-20.11

Sesuai Peraturan Mahkamah Agung Nomor 01 Tahun 2016 tentang Prosedur Mediasi di Pengadilan, terhadap semua sengketa perdata yang diajukan ke pengadilan wajib terlebih dahulu diupayakan penyelesaian melalui mediasi, kecuali ditentukan lain berdasarkan Peraturan Mahkamah Agung tersebut. Pengadilan Agama Sleman sebagai salah satu pelaku kekuasaan kehakiman telah menerapkan mediasi terhadap seluruh perkara yang diajukan padanya termasuk sengketa ekonomi syariah.

Berdasarkan data yang diperoleh dari Pengadilan Agama Sleman, diketahui terdapat 26 perkara Ekonomi Syariah yang diterima oleh Pengadilan Agama Sleman sejak 2014 sampai dengan 2017.12 Dari 26 perkara tersebut, 13 perkara dapat dilakukan mediasi. ${ }^{13}$ Dari 13 perkara yang dapat dimediasi tersebut, 6 perkara dilaporkan mediasi berhasil mencapai kesepakatan dan 7 perkara tidak berhasil. ${ }^{14}$

9 http://www.hukumonline.com/berita/baca/hol20046/iwakaii-dan-ichoteii-prosedur-penyelesaiansengketa-ala-jepang, Akses 9 Agustus 2017.

${ }^{10}$ Katja Funken, Comparative Dispute Management: Court-connected Mediation in Japan and Germany, German Law Jurnal, Volume 3, Issue Number 2, 2002, hlm 5 dalam https://jurnal.ugm.ac.id , "Herliana, Integrasi Mediasi Dalam Sistem Peradilan: Studi Komparatif Mediasi Pengadilan Indonesia dan Jepang,, Mimbar Hukum, Volume 24, No. 1, Tahun 2012, hlm 177, Akses 4 September 2017.

11 Muhammad Saifullah, "Integrasi Mediasi Kasus Perceraian dalam Beracara di Pengadilan Agama", Al Abkam, Jurnal Pemikiran Hukum Islam, Volume 24, Nomor 2, Oktober 2014, hlm 244.

12 Data diperoleh dari Register perkara ekonomi syariah Pengadilan Agama Sleman dan hasil penelusuran Sistim Informasi Penelusuran Perkara Pengadilan Agama Sleman

13 Data diperoleh dari Register perkara ekonomi syariah Pengadilan Agama Sleman, Sistim Informasi Penelusuran Perkara Pengadilan Agama Sleman, Register Mediasi Perkara Ekonomi Syariah dan Putusan hakim serta Berita Acara Sidang perkara ekonomi syariah.

${ }^{14}$ Ibid. 
Keberhasilan mediasi ini, menurut Peneliti masih belum optimal dan masih bisa diupayakan untuk ditingkatkan. ${ }^{15}$

Mengingat peran mediator sangat menentukan efektivitas proses penyelesaian sengketa ${ }^{16}$, sementara diketahui keberhasilan mediasi dalam sengketa ekonomi syariah di Pengadilan Agama Sleman masih belum mencapai hasil yang memuaskan, dimungkinkan juga karena terdapat hambatan-hambatan yang dapat mengurangi maksimalnya peran mediator, maka Peneliti tertarik untuk meneliti lebih lanjut tentang peran mediator beserta hambatan-hambatan yang dihadapi oleh mediator dalam penyelesaian sengketa ekonomi syariah di Pengadilan Agama Sleman tersebut.

\section{Rumusan Masalah}

Berdasarkan latar belakang masalah diatas, dapat dirumuskan permasalahan pokok penelitian sebagai berikut : pertama, bagaimana peran mediator dalam penyelesaian sengketa ekonomi syariah di Pengadilan Agama Sleman ? Kedua, apa hambatan-hambatan yang dihadapi oleh mediator dalam pelaksanaan mediasi sengketa ekonomi syariah di Pengadilan Agama Sleman?

\section{Tujuan Penelitian}

Atas dasar permasalahan tersebut di atas, Penelitian ini bertujuan untuk : pertama, mengkaji dan menganalisis peran mediator dalam penyelesaian sengketa ekonomi syariah di Pengadilan Agama Sleman. Kedua, mengkaji dan menganalisis hambatan yang dihadapi oleh mediator dalam pelaksanaan mediasi sengketa ekonomi syariah di Pengadilan Agama Sleman.

\section{Metode Penelitian}

Jenis penelitian ini adalah penelitian normatif yaitu penelitian yang berfokus pada norma hukum positif. Penelitian hukum normatif menekankan pada langkah-

${ }^{15}$ Dapat juga dibandingkan dengan keberhasilan mediasi perkara Ekonomi Syariah di Pengadilan Agama Purbalingga sebesar 60\% (hasil wawancara dengan H. Hasanuddin, S.H., M.H., Wakil Ketua PA Sleman sekaligus mantan Ketua PA Purbalingga) tanggal 13 Desember 2017 di kantor Pengadilan Agama Sleman, dan keberhasilan praktik wakai di Jepang sebesar 45\%-55\%.

16 Syahrizal Abbas, Mediasi..., Op. Cit., hlm. 60. 
langkah spekulatif teoritis pada peristiwa hukum ${ }^{17}$. Pendekatan yang digunakan dalam penelitian ini adalah pendekatan perundang-undangan dan pendekatan kasus. Pendekatan perundang-undangan dilakukan dengan menelaah undangundang dan regulasi yang terkait dengan isu hukum yang diketengahkan ${ }^{18}$. Pendekatan kasus menggunakan putusan hakim sebagai sumber bahan hukum.

Objek penelitian ini adalah perkara ekonomi syariah yang terdaftar di Pengadilan Agama Sleman dari 2014 sampai dengan 2017 baik yang sudah putus maupun yang masih dalam proses persidangan. Bahan hukum yang digunakan terdiri dari bahan hukum primer, bahan hukum sekunder. Bahan hukum primer adalah bahan hukum yang memiliki otoritas, artinya bersifat mengikat ${ }^{19}$. Bahan hukum primer dalam penelitian ini berupa perundang-undangan dan putusan hakim. Bahan hukum sekunder adalah bahan hukum yang memberikan penjelasan mengenai bahan hukum primer. Bahan hukum sekunder dalam penelitian ini berupa buku-buku hukum, jurnal hukum, hasil penelitian hukum, dan bacaan hukum lain yang terkait dengan permasalahan penelitian ini. Pengumpulan data dilakukan dengan studi kepustakaan dan wawancara.

\section{Hasil Penelitian dan Pembahasan}

Peran Mediator dalam Penyelesaian sengketa Ekonomi Syariah di Pengadilan Agama Sleman.

Sengketa ekonomi syariah adalah merupakan kewenangan Pengadilan Agama. ${ }^{20}$ Meski sempat terjadi problem dualisme penyelesaian sengketa ekonomi syariah secara litigasi karena UU Nomor 21 Tahun 2008 tentang Perbankan Syariah mencantumkan peradilan umum sebagai pilihan untuk menyelesaikan sengketa, namun hal itu telah selesai dengan dikeluarkannya putusan Mahkamah Konstitusi Nomor 93/PUU.X/2012 yang menyerahkan kewenangan absolut penyelesaian sengketa perbankan syariah (yang termasuk dalam bidang ekonomi syariah) kepada Pengadilan Agama.

\footnotetext{
${ }_{17}$ Sabian Utsman, Metodologi Penelitian Hukum Progresif, Cetakan I, Pustaka Pelajar, Yogyakarta, 2014, hlm. 2.

18 Peter Mahmud Marzuki, Penelitian Hukum, Kencana, Jakarta, 2005, hlm. 93.

${ }^{19}$ Dyah Ochtorina Susanti dan A'an Efendi, Penelitian Hukum (Legal research), Sinar Grafika, Jakarta, 2014,

${ }^{20}$ UU Nomor 3 Tahun 2006 Pasal 49
} hlm. 52 . 
Sengketa ekonomi syariah yang diajukan ke Pengadilan Agama Sleman sampai dengan saat ini berupa sengketa tentang pembiayaan syariah antara Bank Syariah dan BMT dengan nasabahnya. Umumnya sengketa ekonomi syariah tersebut diajukan ke Pengadilan Agama Sleman karena Tergugat melakukan perbuatan hukum ingkar janji atau wanprestasi terhadap perjanjian yang telah disepakati sebelumnya.

Wanprestasi pada sengketa ekonomi syariah di Pengadilan Agama Sleman kebanyakan terjadi karena Tergugat melaksanakan prestasi tetapi tidak tepat waktu (terlambat) dan melaksanakan prestasi tetapi tidak seperti yang diperjanjikan. Hampir semua sengketa ekonomi syariah karena Tergugat tidak memenuhi kewajibannya selama beberapa bulan, sehingga pembiayaan Tergugat masuk dalam kolekbilitas macet. Meski telah ditempuh upaya penyelesaian secara kekeluargaan dan penagihan secara optimal bahkan telah dikirim surat peringatan satu sampai surat peringatan ketiga, tetapi Tergugat tetap tidak mau atau tidak mampu melakukan pembayaran. Hal ini selanjutnya memicu permasalahan berikutnya, seperti gugatan wanprestasi melalui pengadilan atau pelelangan sepihak yang dilakukan oleh pihak pemberi pembiayaan/Bank Syariah/BMT.

Sengketa ekonomi syariah yang masuk ke Pengadilan Agama Sleman adalah sebagai berikut 2014 terdapat 1 perkara ekonomi syariah, 2015 terdapat 2 perkara ekonomi syariah, 2016 terdapat 16 perkara ekonomi syariah, 2017 terdapat 7 perkara ekonomi syariah. Jumlah sengketa ekonomi syariah yang masuk ke Pengadilan Agama Sleman dari 2014 sampai dengan 2017 sebanyak 26 perkara.

\section{Mediasi Sengketa Ekonomi Syariah di Pengadilan Agama Sleman.}

Dari 26 sengketa ekonomi syariah yang terdaftar di Pengadilan Agama Sleman, terdapat 13 perkara ekonomi syariah yang dapat dilakukan mediasi. Kenapa belum semua perkara ekonomi syariah di Pengadilan Agama Sleman tersebut dapat dilakukan mediasi? Hal ini menurut peneliti disebabkan oleh beberapa faktor, yaitu:21

${ }^{21}$ Faktor penyebab ini adalah kesimpulan Penulis setelah meneliti berkas perkara ekonomi syariah yang masuk di Pengadilan Agama Sleman, juga bisa dilihat dalam Tesis Penulis yang berjudul "Peran Mediator Dalam Penyelesaian Sengketa Ekonomi Syariah Di Pengadilan Agama Sleman Kelas 1A” hlm. 69. 
a. Salah satu pihak tidak hadir pada sidang yang telah ditentukan, meskipun telah telah dipanggil secara resmi dan patut. Ketidakhadiran salah satu pihak menyebabkan mediasi tidak dapat dilaksanakan, sesuai pasal 4 ayat 2 (b) yang berbunyi sengketa yang pemeriksaannya dilakukan tanpa hadirnya Penggugat atau Tergugat yang telah dipanggil secara patut, dikecualikan dari kewajiban penyelesaian melalui mediasi.22

b. Penggugat telah mencabut gugatannya sebelum dilakukan mediasi karena telah terjadi perdamaian atau kesepakatan antara Penggugat dan Tergugat. Pertemuan untuk mengadakan perdamaian dilakukan diluar sidang pengadilan. Penggugat datang kembali kepersidangan untuk melaporkan bahwa telah terjadi kesepakatan antara Penggugat dan Tergugat .

c. Penggugat mencabut gugatannya karena berubah pikiran atau alasan akan memperbaiki gugatannya terlebih dahulu.

Dari 13 perkara sengketa ekonomi syariah yang dapat dimediasi, 6 perkara dilaporkan mediasi berhasil mencapai kesepakatan dan 7 perkara dilaporkan mediasi tidak berhasil mencapai kesepakatan.

\section{Mediator dan Perannya dalam Mediasi Sengketa Ekonomi Syariah di Pengadilan Agama Sleman.}

Mediator yang terdaftar di Pengadilan Agama Sleman terdiri dari mediator hakim dan mediator nonhakim. Penunjukan mediator berdasarkan Surat Keputusan Ketua tentang Penunjukan Mediator Pengadilan Agama Sleman. Surat Keputusan tersebut juga menetapkan jadwal tugas mediasi.

\section{Peran Mediator dalam Tahapan Proses Pra-Mediasi}

Dalam tahap pramediasi Hakim Pemeriksa Perkara mewajibkan para pihak untuk menempuh mediasi. ${ }^{23}$ Selanjutnya Ketua Majelis menjelaskan kepada para pihak tentang pengertian dan tata cara mediasi. Setelah para pihak memahami dan mengerti isi penjelasan mediasi kemudian para pihak menandatangani penjelasan mediasi tersebut. ${ }^{24}$ Penjelasan mediasi ini dimaksudkan agar para pihak mengerti alasan keharusan dilakukannya mediasi, manfaat mediasi bagi para pihak, tata cara mediasi, dan hak serta kewajiban para pihak dalam mediasi, sehingga meningkatkan kepedulian para pihak akan arti pentingnya mediasi.

\footnotetext{
22 Perma Nomor 1 Tahun 2016 Pasal 4 ayat (2 b)

23 Perma Nomor 1 Tahun 2016 Pasal 17 ayat (1).

24 Perma Nomor 1 Tahun 2016 Pasal 17 ayat (9).
} 
Selanjutnya Ketua Majelis akan memberikan penjelasan juga kepada para pihak tentang haknya untuk memilih mediator, ${ }^{25}$ baik mediator hakim maupun mediator nonhakim bersertifikat yang terdaftar di Pengadilan Agama Sleman. Termasuk penjelasan tentang biaya dan tempat mediasi. Apabila para pihak memilih mediator hakim akan bebas biaya mediasi dan tempat yang digunakan adalah ruang mediasi di Pengadilan Agama Sleman yang bisa digunakan secara bebas biaya. Namun bila para pihak memilih mediator nonhakim, maka mengenai besaran biaya ditanggung bersama atau diserahkan kepada kesepakatan antara para pihak dengan mediator yang ditunjuk. ${ }^{26}$

Jika para pihak memilih mediator nonhakim, maka boleh memilih pelaksanaan mediasi di ruang mediasi Pengadilan Agama Sleman, yang berarti penggunaan tempatnya adalah bebas biaya, atau bila memilih tempat diluar ruang mediasi Pengadilan Agama Sleman, maka biayanya adalah menjadi tanggungan atau kewajiban para pihak sesuai kesepakatan mereka.

Faktor biaya inilah yang umumnya menjadi alasan utama kenapa sampai dengan saat ini semua perkara yang dilakukan mediasi termasuk perkara ekonomi syariah, para pihak hampir selalu sepakat menyerahkan pemilihan mediator kepada Majelis Hakim. ${ }^{27}$ Selanjutnya Majelis hakim akan menunjuk mediator yang terdaftar di Pengadilan Agama Sleman sesuai dengan jadwal yang telah dibuat berdasarkan Surat Keputusan Ketua Pengadilan Agama Sleman.

Peran mediator dalam tahapan pramediasi ini baru sebatas menentukan hari dan tanggal pertemuan mediasi, meskipun dalam praktek pelaksanaan mediasi di Pengadilan Agama Sleman, untuk lebih efektif dan efisien waktu dan biaya, hari dan tanggal mediasi pertama dilakukan sama dengan hari dan tanggal persidangan perkara yang bersangkutan.

${ }^{25}$ Sesuai Perma Nomor 1 Tahun 2016 Pasal 19

26 Sesuai Perma Nomor 1 Tahun 2016 Bab II tentang Pedoman Mediasi di Pengadilan Bagian keenam tentang Biaya Mediasi Paragraf 1 tentang Biaya Jasa Mediator Pasal 8 dan Bagian ketujuh tentang Tempat Penyelenggaraan Mediasi Pasal 11.

${ }^{27}$ Ini adalah hasil pengamatan Penulis selama 2 tahun sebagai Panitera Pengganti yang mendampingi majelis pemeriksa perkara dalam persidangan di Pengadilan Agama Sleman. (pengamatan dilakukan baik didalam maupun diluar persidangan). 


\section{Peran Mediator dalam Tahapan Proses Mediasi}

Atas dasar penetapan penunjukan mediator oleh Ketua Majelis, selanjutnya mediator mulai melakukan tugasnya. Dalam prakteknya, agar lebih efisien dalam penggunaan waktu dan biaya, para pihak atas perintah Ketua Majelis langsung menghadap mediator di ruang mediasi untuk memulai proses mediasi. Menurut mediator Drs. H. Juhri, M.H. ${ }^{28}$, hal pertama yang dilakukan pada saat memulai proses mediasi adalah saling memperkenalkan diri, penjelasan tentang mediasi dan perannya sebagai mediator yang netral, tidak memihak, tidak mengambil keputusan, serta mengidentifikasi masalah/sengketa. Meskipun mediator sudah memegang berkas gugatan namun identifikasi masalah ini juga dianggap penting jika langsung bertanya kepada para pihak yang bersengketa, karena mediator bisa mengetahui hal yang bersifat pokok yang diminta oleh Penggugat atau ditolak oleh Tergugat.

Pada pertemuan pertama ini mediator juga mendorong para pihak untuk berpikir tentang sengketa dari berbagai segi. Mediator juga menjelaskan jika sengketa bisa diselesaikan dengan damai maka tidak ada pihak yang kalah atau menang, tapi jika sengketa berlanjut ke proses litigasi berarti ada yang kalah dan ada yang menang. Jika dalam pertemuan pertama ini belum menghasilkan kesepakatan sementara mediator melihat ada peluang terjadinya perdamaian maka mediator dengan kesepakatan para pihak akan menentukan jadwal pertemuan berikutnya atau biasa disebut mediasi lanjutan.

Pada suatu perkara, ${ }^{29}$ karena mediasi pada pertemuan pertama belum tercapai kesepakatan maka mediasi dilanjutkan pada pertemuan berikutnya. Masih menurut Drs. H. Juhri, M.H., mediator pada perkara tersebut, pada pertemuan kedua dilakukan kaukus. Kaukus ini bertujuan untuk menggali hal-hal yang tidak terungkap dalam pertemuan mediasi yang dihadiri pihak lawan dan para pihak juga dapat lebih leluasa memberikan usulan kepada mediator mengenai opsi penyelesaian sengketa. Selanjutnya para pihak memberikan usulan opsi penyelesaian dalam kaukus. Dalam tahap kaukus ini, mediator melihat ada

28 Wawancara dengan mediator Drs. H. Juhri, MH tanggal 29 Nopember 2017 di kantor Pengadilan Agama Sleman.

${ }^{29}$ Contoh perkara nomor : 1326/Pdt.G/2016/PA.Smn 
perkembangan kearah perdamaian sehingga mempertimbangkan mediasi masih harus dilanjutkan lagi. Namun sayang pada pertemuan berikutnya Tergugat tidak datang sehingga mediasi tidak berhasil. Mediator menduga pengacara Tergugat mempengaruhi keputusan Tergugat.

Hal yang hampir sama juga disampaikan oleh Drs. H. S. Bakir, S.H., M.H., seorang mediator nonhakim yang terdaftar di Pengadilan Agama Sleman. Untuk menyiasati oknum pengacara yang kurang mendukung pelaksanaan mediasi, Drs. H. S. Bakir, S.H., M.H. yang merupakan mantan Hakim Pengadilan Tinggi Agama Yogyakarta itu terlebih dahulu memanggil pengacara yang mendampingi pihak untuk diberikan penjelasan seperlunya sehingga hakim, mediator dan pengacara berada pada satu pemahaman yang seragam tentang artinya pentingnya mediasi..$^{30}$

Masih menurut mediator Drs. H. S. Bakir, S.H., M.H., seorang mediator harus berusaha membantu pihak untuk menerima dan menghadapi kenyataan, membantu pihak dalam proses tawar menawar, membantu pihak menciptakan pilihan-pilihan penyelesaian yang paling sesuai. Untuk pihak pemberi pembiayaan/Bank Syariah/BMT biasanya disarankan agar mau mengalah dalam arti setidaknya dilunasi hutang pokoknya yang penting tidak merugi. Hingga pada akhirnya para pihak akan ketemu dalam kesepakatan dan mediasi berhasil mencapai kesepakatan. ${ }^{31}$

Hal yang belum dilakukan oleh mediator adalah mengisi formulir jadwal mediasi yang berguna sebagai data untuk melakukan pemantauan dan evaluasi pelaksanaan mediasi. Padahal itu juga adalah salah satu tugas yang harus dilakukan oleh seorang mediator. ${ }^{32}$ Meskipun kewajiban mengisi formulir jadwal mediasi ini tidak terkait langsung dengan peran mediator dalam pelaksanaan mediasi, namun bisa dijadikan bahan untuk menilai seberapa berperannya seorang mediator dalam menjalankan tugasnya. Dari formulir itu dapat dilihat berapa kali

\footnotetext{
${ }^{30}$ Wawancara dengan mediator nonhakim. Drs. H. S. Bakir, S.H., M.H., tanggal 6 Desember 2017 diruang mediasi Pengadilan Agama Sleman.

31 Wawancara dengan mediator nonhakim. Drs. H. S. Bakir, S.H., M.H., tanggal 6 Desember 2017 diruang mediasi Pengadilan Agama Sleman.

32 Lihat Pasal 14 huruf g Peraturan Mahkamah Agung Nomor 1 Tahun 2016 dan Keputusan Ketua Mahkamah Agung Nomor: 108/KMA/SK/VI/2016 tanggal 17 Juni 2016 tentang Administrasi Mediasi di Pengadilan pasal 6 angka 7 .
} 
pertemuan mediasi dilakukan, bagaimana kehadiran para pihak, berapa waktu yang digunakan oleh mediator dalam mediasi suatu perkara.

Hambatan Mediator dalam Pelaksanaan Mediasi Sengketa Ekonomi Syariah di Pengadilan Agama Sleman.

Hambatan yang dihadapi oleh mediator dalam proses mediasi sengketa ekonomi syariah merupakan salah satu faktor penyebab keberhasilan mediasi belum mencapai hasil yang optimal. Untuk menggambarkan mediasi dan tingkat keberhasilannya dapat dilihat pada tabel 1 berikut ini.

Tabel 1.

Mediasi dan Prosentase Keberhasilannya Sengketa Ekonomi Syariah di Pengadilan Agama Sleman Kelas 1A

\begin{tabular}{llllllll}
\hline No Tahun & $\begin{array}{c}\text { Jumlah } \\
\text { Perkara } \\
\text { Masuk }\end{array}$ & $\begin{array}{c}\text { Jumlah } \\
\text { Perkara } \\
\text { dimediasi }\end{array}$ & Berhasil & $\begin{array}{c}\text { Prosentase } \\
\text { Berhasil }\end{array}$ & $\begin{array}{c}\text { Tidak } \\
\text { berhasil }\end{array}$ & $\begin{array}{c}\text { Prosentase } \\
\text { Tidak } \\
\text { Berhasil }\end{array}$ \\
\hline 1 & 2014 & 1 & 0 & 0 & 0 & 0 & 0 \\
2 & 2015 & 2 & 1 & 0 & 0 & 1 & $100 \%$ \\
3 & 2016 & 16 & 9 & 5 & $55.56 \%$ & 4 & $44,44 \%$ \\
4 & 2017 & 7 & 3 & 1 & $33,33 \%$ & 2 & $66,67 \%$ \\
Jumlah & $\mathbf{2 6}$ & $\mathbf{1 3}$ & $\mathbf{6}$ & $\mathbf{4 6 , 1 5 \%}$ & $\mathbf{7}$ & $\mathbf{5 3 , 8 5 \%}$ \\
\hline
\end{tabular}

Dari tabel di atas bisa dilihat bahwa keberhasilan mediasi bervariasi dari tahun ke tahun. Rata-rata masih rendah dan belum menunjukkan hasil yang optimal, apalagi jika disatukan dengan semua jenis perkara yang masuk ke Pengadilan Agama Sleman, maka prosentase keberhasilan mediasi akan lebih rendah jika dibandingkan dengan wakai yang diadopsi kedalam Perma, dimana wakai berhasil mengurangi penumpukan perkara perdata sekitar $45 \%-55 \%$. Hambatan-hambatan yang dihadapi oleh mediator dalam pelaksanaan mediasi sengketa ekonomi syariah di Pengadilan Agama Sleman adalah sebagai berikut :

Pertama, bagi mediator hakim, masalah keterbatasan waktu karena tersita untuk menyelesaikan tugas sebagai penyelesai perkara dan kurangnya keterampilan sebagai mediator merupakan hambatan tugas sebagai mediator. Keterbatasan waktu mediator hakim terkait dengan jumlah perkara yang harus diselesaikan. Dalam seminggu setiap hakim bersidang 3 dan 2 hari tidak 
bersidang. ${ }^{33}$ Hari-hari tidak bersidang digunakan untuk menyelesaikan perkara yang sudah putus atau sidang keliling atau sidang setempat. Dengan beban kerja yang berat seperti itu, sulit bagi hakim mediator untuk memaksimalkan proses mediasi. Keterbatasan waktu yang dimiliki oleh mediator hakim ini menjadikan mediator hakim melakukan mediasi dengan cepat sehingga pelaksanaan mediasi tidak berlangsung secara optimal sesuai jangka waktu yang diatur dalam Perma Nomor 1 Tahun 2016.34 Masalah kurangnya keterampilan sebagai mediator disebabkan karena masih banyak hakim yang menjalankan tugas sebagai mediator belum mendapatkan pelatihan sebagai mediator. ${ }^{35}$ Belum mendapatkan pelatihan sebagai mediator artinya belum memiliki pengetahuan tentang tehnik-tehnik mediasi yang benar sehingga mediator hakim tidak bisa menjalankan tugasnya sebagai mediator dengan benar.

Kedua, mediator tidak mempunyai kompetensi di bidang ekonomi syariah. Belum semua mediator baik mediator hakim maupun mediator nonhakim mempunyai kompetensi di bidang ekonomi syariah. ${ }^{36}$ Kompetensi dibidang ekonomi syariah ini penting sekali sebagai bekal mediator sengketa ekonomi syariah. Mediasi pada sengketa ekonomi syariah selain teknik mediasi juga harus ahli pada bidang yang disengketakan yaitu bidang ekonomi syariah. Hal itu akan semakin menguatkan perannya sebagai mediator sengketa ekonomi syariah yang ujungnya adalah keberhasilan mediasi.

Ketiga, ketidakhadiran salah satu pihak dalam mediasi. Sengketa yang pemeriksaannya dilakukan tanpa hadirnya penggugat atau tergugat yang telah dipanggil secara patut adalah sengketa yang dikecualikan dari kewajiban penyelesaian melalui mediasi. ${ }^{37}$ Karena tidak ada aturan yang memaksa pihak yang tidak hadir (terutama tergugat) dalam persidangan untuk melaksanakan

\footnotetext{
${ }^{33}$ Surat Keputusan Ketua tentang Penunjukan Majelis Hakim.

34 Perma Nomor 1 Tahun 2016 Pasal 24 mengatur bahwa jangak waktu mediasi paling lama 30 hari dan bisa diperpanjang paling lama 30 hari.

${ }^{35}$ Data dari Bagian Kepegawaian PA Sleman dari 10 hakim baru ada 2 hakim yang mendapatkan pelatihan mediator.

${ }^{36}$ Berdasarkan data yang ada di Kepaniteraan PA Sleman masih terdapat mediator baik hakim maupun nonhakim yang tidak mempunyai sertifikat ekonomi syariah.

37 Perma Nomor 1 Tahun 2016 Pasal 4 ayat (2) huruf b.
} 
mediasi maka hanya sebagian kecil saja dari perkara yang masuk ke pengadilan yang dapat dilakukan mediasi. Hal ini semakin memperkecil kemungkinan keberhasilan mediasi. Di sisi lain, dalam praktek pelaksanaan mediasi di Pengadilan Agama Sleman, kedua belah pihak yang hadir dipersidangan sesaat setelah selesai sidang di ruang sidang lalu keluar menuju ruang mediasi Pengadilan Agama Sleman untuk melaksanakan proses mediasi (tentu ini berlaku untuk para pihak yang menyerahkan penunjukan mediator pada Majelis Hakim pemeriksa perkara). Kebijakan ini dilakukan oleh pimpinan agar tidak perlu ada biaya yang dikeluarkan untuk memanggil para pihak untuk melaksanakan mediasi. ${ }^{38}$ Ini akan meringankan beban biaya pihak berperkara. Jika dalam pertemuan berikutnya ada pihak yang tidak hadir barulah mediator akan memanggil pihak melalui panitera. Namun hal ini sebagian belum bisa dilaksanakan karena masih ada pemahaman yang berbeda tentang siapa yang berwenang memberikan perintah pemanggilan mediasi kepada jurusita, apakah mediator atau Ketua Majelis. Perbedaan pandangan itu menyebabkan mediator belum bisa memangggil pihak yang tidak menghadiri pertemuan mediasi, sehingga mediator dengan usaha dan biaya sendiri menghubungi pihak agar menghadiri pertemuan mediasi berikutnya. ${ }^{39}$

Keempat, faktor Gengsi para pihak.$^{40}$ Kesulitan keberhasilan mediasi juga karena terdapat faktor gengsi salah satu pihak yang tinggi terutama jika sudah menyangkut harta dan harga diri. Misalnya dalam suatu kasus peminjam meskipun telah nyatanyata tidak dapat membayar sisa pinjaman, namun setelah diberi keringanan dan waktu tangguhan tetap masih bersikukuh tidak mau menyepakati keringanan yang diberikan oleh pemberi pembiayaan/pihak bank karena merasa direndahkan atau dianggap tidak mampu membayar. Pemberi pembiayaan/pihak bank juga akan bersikap mendesak, lebih-lebih yang diwakili oleh advokat.

Kelima, faktor Pengacara. Ada dugaan adanya oknum pengacara yang tidak mendukung sepenuhnya proses mediasi. Pada satu kasus sengketa ekonomi syariah yang dimediasi oleh mediator, pada saat mediasi telah dilihat ada

38 Wawancara dengan Panitera Pengadilan Agama Sleman, Drs. Arwan achmad, tanggal 24 Nopember 2017 di kantor Pengadilan Agama Sleman.

${ }^{39}$ Wawancara dengan mediator nonhakim. Drs. H. S. Bakir, S.H., M.H., tanggal 6 Desember 2017

40 Wawancara dengan mediator nonhakim. Drs. H. S. Bakir, S.H., M.H., tanggal 6 Desember 2017. 
perkembangan kearah kesepakatan. Namun pada pertemuan berikutnya salah satu pihak tidak pernah datang lagi diduga karena pengaruh pandangan dari pengacaranya. Hal ini menurut mediator tersebut bisa saja terjadi karena honor yang akan diterima oleh Pengacara tersebut akan jauh lebih kecil jika perkara berlanjut ke persidangan. Karena suatu perkara yang selesai pada tahap mediasi berarti frekuensi kunjungan Pengacara ke persidangan menjadi terpangkas dan itu mempengaruhi honor yang diterima.

Keenam, Prasarana dan sarana mediasi. Ruang mediasi adalah salah satu sarana yang menunjang keberhasilan mediasi. Mediasi yang dilakukan di Pengadilan terkesan formal, dimana yang terkesan formal itu biasanya akan melahirkan ketegangan. Ketegangan hanya akan memicu tingkat emosi yang tinggi. Sifat yang demikian tidak akan produktif bagi proses mediasi. Menurut Pasal 8 Keputusan Ketua Mahkamah Agung Nomor: 108/KMA/SK/VI/2016 tentang Administrasi Mediasi di Pengadilan ruang mediasi diupayakan meliputi ruang pertemuan bersama, ruang pertemuan sepihak (kaukus) dan ruang tunggu. Ruang mediasi Pengadilan Agama Sleman baru mempunyai satu ruangan berukuran $3 \mathrm{~m} \times 3 \mathrm{~m}$. Biasanya untuk perkara sengketa ekonomi syariah dalam pelaksanaan mediasi dalam suatu waktu pertemuan bisa terdapat 4 orang atau lebih yang masuk keruang mediasi. Pihak Bank biasanya diwakili oleh advokat yang lebih dari satu orang demikian pula pihak peminjam. Dengan ruangan yang terbatas, dipenuhi orang yang notabene sedang bermasalah tentu akan menjadi ketidaknyamanan tersendiri bagi pelaksanaan mediasi. Ruang pertemuan sepihak (kaukus) dan ruang tunggu mediasi belum ada.

Ketujuh, Antrian mediasi. Belum adanya sistim antrian elektronik untuk mediasi sering menganggu mediasi yang sedang berjalan. Pihak masuk ke ruang mediasi ketika ada mediasi yang sedang dilakukan, sehingga mediasi harus dihentikan sementara untuk memberikan penjelasan seperlunya. Hal ini bisa membuyarkan konsentrasi mediator dan para pihak yang sedang mencari jalan menuju kesepakatan.

Kedelapan, biaya bagi mediator. Untuk meringankan biaya bagi para pihak dalam proses mediasi, Ketua Pengadilan Agama Sleman telah mengeluarkan Surat 
Keputusan tentang panjar biaya perkara. Dalam panjar biaya perkara itu sudah termasuk biaya untuk mediasi sebesar Rp. 100.000,- perperkara untuk mediator nonhakim yang terdaftar di Pengadilan Agama Sleman. Padahal ada kalanya satu perkara dimediasi sampai 6 kali pertemuan. Mediator mengharapkan ada kebijakan dari pimpinan agar lebih diperhatikan.

\section{Penutup}

Dari hasil pembahasan dapat diambil kesimpulan bahwa peran mediator dalam penyelesaian sengketa ekonomi syariah secara keseluruhan belum optimal dikarenakan adanya beberapa hambatan yang dihadapi mediator, meskipun untuk beberapa kasus sudah terlihat peran yang kuat dari seorang mediator dengan hasil tercapainya kesepakatan. Hal ini sudah dapat mengurangi jumlah perkara ekonomi syariah yang harus diperiksa/diselesaikan oleh hakim Pengadilan Agama Sleman namun belum signifikan, apalagi jika disatukan dengan semua jenis perkara perdata yang masuk di Pengadilan Agama Sleman maka akan semakin kecil pengurangannya.

Belum optimalnya peran yang dilakukan oleh mediator juga bisa dilihat dari mediator yang belum sepenuhnya menjalankan tugas sesuai dengan Peraturan Mahkamah Agung Nomor 1 Tahun 2016 tentang Prosedur Mediasi di Pengadilan seperti belum digunakannya jangka waktu maksimal untuk mediasi beserta waktu perpanjangannya .

Untuk meningkatkan peran mediator dalam penyelesaian sengketa ekonomi syariah dan mengatasi hambatan mediator dalam pelaksanaan mediasi sengketa ekonomi syariah di Pengadilan Agama Sleman perlu dilakukan langkah-langkah sebagai berikut:

Pertama, mengusulkan kepada Mahkamah Agung untuk menambah jumlah hakim agar sesuai dengan jumlah ideal hakim yang harus ada pada pengadilan sesuai kelasnya dan melaporkan kepada Mahkamah Agung data hakim yang belum mempunyai sertifikat mediator. Kedua, mengusulkan dan melaporkan kepada Mahkamah Agung tentang kebutuhan hakim untuk mendapatkan pendidikan dan pelatihan ekonomi syariah. Ketiga, revisi terhadap Peraturan Mahkamah Agung Nomor 1 Tahun 2016, yaitu kewajiban bagi Ketua Majelis 
Hakim untuk melakukan pemanggilan bagi pihak yang tidak hadir dalam persidangan untuk hadir melaksanakan mediasi. Keempat, untuk mengatasi adanya oknum pengacara yang tidak mendukung sepenuhnya proses mediasi ini hendaknya dilakukan penjelasan secara tersendiri oleh mediator terhadap pentingnya mediasi dan fungsi profesi pengacara. Selain itu juga perlu dibuat regulasi dari Mahkamah Agung bekerja sama dengan organisasi Pengacara tentang aturan kewajiban pengacara mendukung proses mediasi. Kelima, ruang mediasi dibuat senyaman mungkin seperti pengaturan warna cat dalam ruangan mediasi yang menimbulkan suasana damai, penataan interior ruang mediasi bisa dihiasi dengan bunga, pewangi ruangan yang bersifat aromaterapi yang dapat membantu menenangkan dan menstabilkan emosi para pihak, ornamen-ornamen yang menggugah semangat perdamaian misalnya ayat Al-Quran atau hadist tentang perdamaian dan kata mutiara. Keenam, antrian mediasi bisa diatasi dengan pengadaan/pembelian mesin antrian mediasi elektronik, sehingga pihak cukup menunggu diluar ruang mediasi dan masuk hanya ketika namanya dipanggil secara elektronik. Memakai alat yang lebih sederhana juga bisa dilakukan misalnya dengan mik/pengeras suara. Ini juga untuk mengantisipasi pihak yang menunggu jauh dari ruang mediasi agar bisa mendengar panggilan karena ruang tunggu khusus mediasi belum ada. Berkas antrian mediasi cukup petugas administrasi yang mengatur. Petugas administrasi selain bertanggungjawab atas ketersediaan formulir-formulir mediasi juga membantu mediator untuk kelancaran pelaksanaan mediasi.

\section{Daftar Pustaka}

\section{Buku}

Abbas, Syahrizal, Mediasi dalam Perspektif Hukum Syariah, Hukum Adat, dan Hukum Nasional, Kencana, Jakarta, 2009.

Dewi, Gemala et. al., Hukum Perikatan Islam di Indonesia, Kencana, Jakarta, 2007. Kitab Sunan Abi Dawud, jilid 2, Hadist No. 3594.

Marzuki, Peter Mahmud, Penelitian Hukum, Kencana, Jakarta, 2005.

Rajagukguk, Erman, Arbitrase dalam Putusan Pengadilan, Cetakan I, Chandra Pratama, Jakarta, 2000. 
Rosyadi, A Rahmat dan Ngatino, Arbitrase dalam Perspektif Islam dan Hukum Positif, Cetakan I, Citra Aditya Bakti, Bandung, 2002.

Sabik, Sayid, Fiqh Sunnah, Juz 3, Dar al-Fath, Kairo, 2000.

Susanti, Dyah Ochtorina dan A'an Efendi, Penelitian Hukum (Legal research), Sinar Grafika, Jakarta, 2014.

Utsman, Sabian, Metodologi Penelitian Hukum Progresif, Cetakan I, Pustaka Pelajar, Yogyakarta, 2014.

\section{Jurnal}

Saifullah, Muhammad, "Integrasi Mediasi Kasus Perceraian dalam Beracara di Pengadilan Agama", Al Ahkam, Jurnal Pemikiran Hukum Islam, Volume 24, Nomor 2, Oktober 2014

\section{Peraturan Perundang-undangan}

UU Nomor 3 Tahun 2006 Pasal 49.

Peraturan Mahkamah Agung Nomor 01 Tahun 2016.

Keputusan Ketua Mahkamah Agung Nomor: 108/KMA/SK/VI/2016 tanggal 17 Juni 2016 tentang Administrasi Mediasi di Pengadilan.

\section{Internet}

http:/ / www.hukumonline.com/berita/baca/hol20046/iwakaii-dan-ichoteiiprosedur-penyelesaian-sengketa-ala-jepang, Akses 9 Agustus 2017.

http:/ / quran.kemenag.go.id/., akses tanggal 27 Agustus 2017.

Katja Funken, Comparative Dispute Management: Court-connected Mediation in Japan and Germany, German Law Jurnal, Volume 3, Issue Number 2, 2002, hlm 5 dalam https://jurnal.ugm.ac.id, Herliana, Integrasi Mediasi Dalam Sistem Peradilan: Studi Komparatif Mediasi Pengadilan Indonesia dan Jepang, Mimbar Hukum, Volume 24, No. 1, Tahun 2012, hlm 177, Akses 4 September 2017. 